\title{
Empirical Study of an Individual's Basic Beliefs in the Context of Overcoming Life Crises
}

\section{Емпіричне дослідження базисних переконань особистості в контексті подолання життєвих криз}

Nataliia Tavrovetska

Ph.D. in Psychology, Assistant Professor

\author{
Наталія Тавровецька \\ кандидат психологічних наук, \\ доцент
}

E-mail:1882181@gmail.com orcid.org/0000-0002-9497-7386

Researcher ID: E-6605-2019

\author{
Kherson State University, \\ Kherson, Ukraine \\ 27, University street, \\ Kherson, Ukraine, 73000
}

Херсонський державний університет, м. Херсон, Украӥна

вул. Університетська, 27, м. Херсон, Україна, 73000

Original manuscript received April 10, 2019 Revised manuscript accepted May 02, 2019

\section{ABSTRACT}

The article deals with the theoretical and practical approaches in the study of the basic beliefs of the individual in the context of overcoming life crises. The concept of "basic beliefs» is analyzed from the cognitive, social, existential position. It is noted that a traumatic stressful event is an experience of acute and sudden collision of human beliefs with reality, and the course of the crisis will depend on an individual's vitality, on the level of violation of semantic connections in the structure of the individual's life world, which is the basis of loss within the meaning.

The concept of $R$. Janoff-Bulman's basic beliefs is analyzed, which explains how the individual constructs his ideas about the world and the self. 
Basic beliefs are necessary internal support in a changing reality, which promotes the mental stability of a man and his success in life, and is also an important condition for personal development. But the basic beliefs are changed under the influence of mental trauma, because extreme negative experience is sharply contrary to the described life concept.

A set of methods and techniques was used to determine the level and content of autobiographical stress: the method of structured diagnostic interviews ("Significant life events») to obtain a general picture of the positive and negative autobiographical events, the closed questionnaire "The list of stressful events" with an assessment of the significance of their impact on emotional, cognitive, and behavioral levels and the World Assumptions Scale (R. Janoff-Bulman).

The level of biographical stress in the life of modern Ukrainians is determined, which is represented by a wide range of crisis situations, including the most difficult ones. The representation of stressful events of all-embracing nature is high. They are natural and technical disasters, repeated economic crises, socio-political upheavals and military conflict.

A correlation analysis has been conducted proving that the more human life is saturated with stressful events, the lower a human being evaluates the significance of their influence on his emotions, cognition and behavior, and to a lesser degree he demonstrates the ability to overcome crises by personal growth. It is concluded that the saturation of life with crisis events negatively affects the basic beliefs about the benevolence of the world and people and, at the same time, positively correlates with the conviction of controllability of the world.

Key words: basic beliefs, life crises, autobiographical stress, emotional, behavioral and cognitive behavior.

\section{Вступ}

Кризова проблематика особистості набуває все більшої актуальності як для практичної психології, так і для теоретичного пошуку. Жћиття людини насичене різноманітними ситуаціями: як звичними, повсякденними, так і непередбачуваними, екстремальними, загальний зміст яких об'єднується в понятті життєвих криз. В умовах болісних соціальних, економічних, політичних трансформацій українського суспільства, що відбуваються в останні роки, кризові процеси набувають максимального поширення i 
гострого характеру. Наповненість навколишнього середовища стресовими чинниками викликає постійне емоційне напруження, що суттєво ускладнює переживання індивідуальних криз.

Важливість життєвих криз зумовлена тим, що вони кардинально порушують сприйняття зовнішнього світу як стабільного, справедливого та безпечного. Це, у свою чергу, дезорганізує внутрішній світ людини, найбільше впливаючи на вершинні компоненти особистості - самосвідомість, ідентичність, ціннісну спрямованість, життєву позицію і життєву програму. У випадку негативного вирішення життєва криза накладає відбиток на все життя людини, викликаючи зневіру не тільки в добро і справедливість, у людях, але й у себе, власні сили і можливості. У разі конструктивного розв'язання криза, навпаки, виявляється могутнім джерелом особистісного зростання, розширює

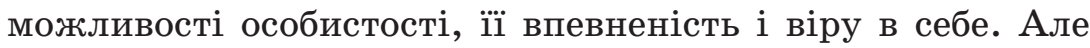
для адекватного подолання неминучих життєвих криз людина повинна змінити свої базисні переконання, побудувати нову «Я-концепцію», аби відповідати новому образу навколишнього світу.

Поняття «базисні переконання» (basic assumptions, basic believes) розвивається на перетині когнітивної, соціальної, клінічної психології та психотерапії, які (кожна зі своїх позицій) намагаються відповісти на питання про те, яким чином індивід конструює уявлення про навколишній світ і власне «Я». У західній психології для позначення сукупності базисних переконань, що забезпечують людині опору, захист і почуття реальності, використовують словосполучення assumptive world - дослівно «світ припущень» (Beder, 2004). У вітчизняній психології найближчим до цього конструкту є поняття «внутрішня картина світу» (Падун \& Котельникова, 2012). Загалом, базисні переконання можна визначити як імпліцитні, глобальні, стійкі уявлення індивіда про світ і про себе, котрі мають вплив на мислення, емоційні стани і поведінку людини. 
Особливий інтерес становить диспозиційна модель структури особистості В. Ядова. Диспозиції представляють собою комплекс готовності свідомості й нервової системи людини діяти певним чином. Такі позиційні утворення виникають щоразу при зустрічі певної потреби з відповідною ситуацією її потенційного задоволення. Вони організовані ієрархічно й утворюють чотири рівні. Установки першого рівня регулюють безпосередні реакції на актуальну предметну ситуацію. Другий рівень регулює вчинки у звичних ситуаціях взаємодії з оточенням. Третій рівень забезпечує регуляцію системи вчинків особистості. Ціннісний рівень регулює поведінку людини у значущих аспектах соціальної активності, зокрема, у проблемних, конфліктних чи в ситуаціях морального вибору. Ця модель дозволяє ставити запитання - на якому саме рівні (або рівнях) відбувається адаптація й трансформація базисних установок, що супроводжує критичні періоди життя (Ядов, 2013).

Із точки зору екзистенційної психології травматична стресова подія є досвідом гострого і раптового зіткнення переконань людини з реальністю, й перебіг кризи залежатиме від життєстійкості людини. У своїх працях американські психологи С. Кобейс і С. Мадді зазначають, що життєстійкість складається з трьох компонентів: залученості, контролю і прийняття ризику (Kobasa, 1979; Maddi, 2004). Українська дослідниця О. Чиханцова визначає життєстійкість як багаторівневе, цілісне утворення, що включає рівні, відповідні ієрархічній структурі властивостей особистості. Жћиттєстійкість - це цілісна система взаємовідносин зі світом, це той необхідний ресурс, який може сприяти підвищенню фізичного і психічного здоров'я людини й пов'язаний із самореалізацією, самоствердженням і трансценденцією особистості (Чиханцова, 2018: 213).

На думку Є. Осіна, під час подолання життєвих криз людина переживає слислове відчуження - порушення смислових зв'язків у структурі життєвого світу особистості, що лежить в основі смисловтрати. Феномен відчуження 
проявляється внаслідок порушення системи зв'язків життя людини зі світом, коли вони позбавлені для індивіда позитивного сенсу i не здатні виступити енергетичною та смисловою основою для повноцінної дії у світі. Підсумком неможливості побудувати свою життєдіяльність на основі внутрішнього смислу стає її побудова на інших, примітивніших засадах: біологічних потребах і соціальних нормах (Osin, 2008).

Із точки зору когнітивної психології використовуються поняття «когнітивні схеми», «конструкти», «переконання», «когніції», за допомогою яких люди структурують власний досвід і формують поведінку. На думку Дж. Келлі (Келли, 2000), процес мислення людини проходить на підставі формування полярних тверджень (конструктів). Прагнення уникати невизначеності призводить до вибору за принципом «або - або», а прагнення компенсувати тривогу, викликану базисним конфліктом, i «принцип задоволення» визначають вибір тієї чи іншої полярності.

Найповніше цей процес постає в концепції базисних (базових) переконань Р. Янофф-Бульман, який пояснює, як саме індивід конструює свої уявлення про навколишній світ і власне «Я». Базисні переконання народжуються в дитинстві й загалом забезпечують почуття захищеності, довіри до світу. Це необхідна внутрішня опора в мінливій реальності, що сприяє психічній стабільності людини та iii успішності в житті, а також є важливою умовою особистісного розвитку. Але базові переконання змінюються під впливом психічної травми, адже екстремальний негативний досвід різко суперечить описаній концепції життя. Його осмислення викликає важкі й тривалі психологічні проблеми: індивід стикається 3 жахами навколишнього світу, а також із власною вразливістю і безпорадністю. Упевненість у власній захищеності виявляється ілюзією, що вводить особистість у стан дезінтеграції. Почуття безпорадності, втрати контролю над власним життям може зберігатися ще довгий час після того, як зникнуть первинні 
симптоми. Відповідно, процес подолання травми полягає у відновленні базисних переконань. У разі успіху вони трансформуються, стають якісно іншими, що звільняє людину від ілюзії власної невразливості (Janoff-Bulman, 1992: 256).

У вітчизняній психології в останні роки популярна концепиія усвідолленого життєтворення. Т. Титаренко пропонує класифікацію посттравматичного життєтворення на основі запропонованого Н. Талебом (Талеб, 2016) популярного поняття «антикрикхість». Антикрихкі особистості легко живуть і відносно добре почуваються в умовах непередбачуваності, невизначеності, випадковості, оскільки вміють модифікувати власні стратегії життєбудови відповідно до різноманітних випадковостей - як позитивних, так і негативних. Потенційно травматичні ситуації не стають для них однозначно негативними подіями, як це відбувається з «особистостями крихкими»; вони можуть узагалі не отримати статус включених у життєву історію подій, залишившись окремими малоприємними епізодами, а можуть навіть змінити емоційну валентність, перетворитися на події більше позитивні, ніж негативні. Травматична подія сприймається насамперед як інформація, що сприятиме подальшому руху життєвим шляхом. У історії життя антикрихкої особистості, котра пережила кризу або травму, виникають почуття спільності з особами, які зазнали травматичний епізод, стійкості, підвищується витривалість, самоповага, оптимізм. Ці позитивні зміни сприяють глибшій інтерпретації події, органічній інтеграції набутого досвіду, побудові більш автентичного оповідання про себе. Постійне самонавчання такої особистості, зростання їі готовності до змін, конструктивне ставлення до власних помилок забезпечують більшу повноту життя та продуктивну взаємодію із собою, світом, іншими людыми (Титаренко, 2018: 8).

Отже, будь-яка криза - це вибір. Або захищати внутрішню картину від будь-яких зовнішніх доказів її неправильності, або спробувати сформувати нову картину оточуючого світу. Другий шлях вимагає перебудови смислових 
структур свідомості та переорієнтування на нові життєві завдання, що ведуть до зміни характеру діяльності.

Мета статті - емпірично дослідити базисні переконання особистості, які визначають і впливають на контекст подолання життевих криз.

\section{Завдання статті}

1. Представити результати вимірювання загального рівня біографічного стресу - поняття, що означає сумарний ефект усіх стресових чинників, що впливають на людину впродовж певного періоду життя, наприклад року.

2. Розкрити результати вимірювання базисних когнітивних переконань особистості у період життя з кризовими подіями.

\section{Методи та методики дослідження}

При вимірюванні загального рівня біографічного стресу мають значення як позитивні, так і негативні емоційнонавантажені життєві епізоди, адже дія емоційної напруги, незалежно від джерела їі виникнення, накопичується i, врешті-решт, якась незначна подія може стати «останньою краплею», причиною зриву або хвороби. Ми розробили дві авторські методики, спрямовані на визначення рівня та змісту автобіографічного стресу: метод структурованого діагностичного інтерв’ю («Значущі життєві події») для отримання загальної картини позитивної і негативної подієвості автобіографії та закриту анкету «Список стресових подій» з оцінкою значущості їх впливу на емоційному, когнітивному та поведінковому рівнях.

За матеріалами теоретичного огляду ми склали детальний перелік подій, які переживаються особистістю як критичні. На основі цього переліку розробили спеціальну процедуру для оцінки насиченості життя людини кризовими подіями, що має характер закритої письмової анкети. У першу чергу, ми відмовилися від стандартної шкали оцінювання стресової події (адже відомо, що одна і та сама 
ситуація по-різному впливає на окремих людей). Деякі ситуації, що вважаються стресовими для всіх людей, виявляються кризами для тих, хто особливо вразливий до них у силу своїх особистісних особливостей, а інших людей майже не зачіпають.

Натомість уведено запитання: Наскільки сильно вплинула на Вас подія? Оиініть за 10-бальною шкалою, враховуючи знак елоції: позитивний або негативний вплив ( «+» або «-»). Така процедура дає нам змогу визначити і вирахувати суб'єктивну значущість події для конкретної людини, причому в різних аспектах, що відповідають загальноприйнятим компонентам життєвої позиції особистості: емоційному - як безпосереднє переживання ставлення; інтелектуальному - як знання про щось, суб'єктивний образ об’єкта ставлення; поведінковому, що реалізує спосіб активності стосовно об'єкта ставлення.

За результатами опитування ми розрахували низку індивідуальних кількісних параметрів:

1) стресогенність останнього року - загальна кількість стресових подій за минулий рік;

2) біографічний стрес - загальна кількість стресових подій за все життя;

3) суспільний стрес - непереборні порушення звичного способу життя всієї спільноти (міста, регіону, країни);

4) ступінь суб'єктивної значущості стресових подій на різних рівнях: емоційному, когнітивному, поведінковому

Співвідношення цих показників демонструє індивідуальний стиль реагування на складні життєві ситуації.

Ці параметри ми порівняли з результатами психологічної діагностики базисних переконань особистості. Шкала базисних переконань «World Assumptions Scale» розроблена на основі теорії психічної травми Р. Янофф-Бульман й адаптована без стандартизації О. О. Кравцовою (JanoffBulman, 1992; Кравцова, 2000). Когнітивна картина світу в рамках методики описується з точки зору переконань про доброзичливість навколишнього світу, його справед- 
ливість і переконань індивіда стосовно цінності та значущості власного «Я».

Для обробки й інтерпретації отриманих даних ми застосували такі математично-статистичні процедури: контент-аналіз відомостей діагностичного інтерв'ю; частотний аналіз для визначення поширеності окремих феноменів у вибірці; підрахунок середніх тенденцій; кореляційний аналіз, що дав змогу виявити взаємозв'язки між насиченістю життя стресовими подіями й основними базисними переконаннями особистості щодо себе та світу.

У дослідженні брали участь 40 осіб (18 чоловіків і 22 жінки, віком від 20 до 52 років). Особливістю цієї категорії опитуваних є те, що це дорослі особи, котрі вже мають певний життєвий досвід, у тому числі досвід подолання життєвих труднощів і самовизначення.

\section{Результати та дискусії}

Як показали результати опитування, у житті сучасних українців представлений широкий діапазон стресових ситуацій, включаючи найважчі. Найвищий відсоток поширеності у вибірці мають такі стресові події: проживання скривдження, образ, зради (повторюване, впродовж усього життя), конфліктні відносини з найближчими людьми, втрата друзів, зміни місця проживання та звичного способу життя. Ці ситуації можна вважати нормальними життєвими випробуваннями, які доводиться переживати мало не кожній людині. Крім того, для дорослих українців характерний високий рівень представленості у житті стресових подій, що носять всезагальний характер: природні та техногенні катастрофи, неодноразові економічні кризи, соціально-політичні потрясіння, військовий конфлікт. Цікаво, що люди одного віку, які виховувались в однакових соціальних умовах і переживали одні й ті самі події в країні, при заповненні анкети відзначають їх по-різному. I тут річ не тільки у вибірковій соціальній пам'яті, але й у загальній схемі світу, яким його сприймає особистість. 
Представленість стресових подій у житті та їх впливовість $(\mathrm{N}=40)$

\begin{tabular}{|c|c|c|c|c|}
\hline \multirow[b]{2}{*}{ Перелік стресових подій } & \multirow{2}{*}{$\begin{array}{c}\text { Частка } \\
\text { опитаних, що } \\
\text { мають досвід }\end{array}$} & \multicolumn{3}{|c|}{\begin{tabular}{|c|} 
Середня оцінка \\
впливу за \\
10-бальною \\
шкалою \\
\end{tabular}} \\
\hline & & 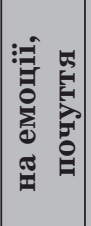 & 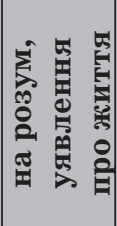 & 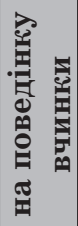 \\
\hline 1 & 2 & 3 & 4 & 5 \\
\hline Смерть близької людини & 28 осіб, $70 \%$ & $-7,8$ & 3,2 & 0,6 \\
\hline $\begin{array}{l}\text { Важка й тривала хвороба } \\
\text { близької людини } \\
\end{array}$ & 18 осіб, $45 \%$ & $-6,5$ & 5,8 & 7,2 \\
\hline $\begin{array}{l}\text { Важке захворювання або травма, } \\
\text { що викликає страх смерті } \\
\end{array}$ & 3 особи, 7,5\% & $-8,5$ & 7,7 & 8,5 \\
\hline \begin{tabular}{|l|} 
Виникнення непрацездатності на \\
більш-менш тривалий період
\end{tabular} & 4 особи, $10 \%$ & $-3,2$ & 0,8 & 1,2 \\
\hline $\begin{array}{l}\text { Фізичне насилля, загроза } \\
\text { особистій безпеці }\end{array}$ & 10 осіб, $25 \%$ & $-4,1$ & 2,2 & 0,5 \\
\hline Жертва шахрайства, обману & 9 осіб, $22,5 \%$ & $-7,3$ & 5,0 & 5,5 \\
\hline $\begin{array}{l}\text { Проживання скривдження, } \\
\text { образ, зради }\end{array}$ & 40 осіб, $100 \%$ & $-5,2$ & 3,9 & 4,1 \\
\hline $\begin{array}{l}\text { Раптова зміна фінансового } \\
\text { становища, соціального статусу, } \\
\text { оточення }\end{array}$ & 25 осіб, $62,5 \%$ & $+1,2$ & 3,7 & 3,8 \\
\hline Одруження, весілля & 33 особи, $82,5 \%$ & $+7,5$ & 6,4 & 7,1 \\
\hline $\begin{array}{l}\text { Розлучення, розрив із коханою } \\
\text { людиною }\end{array}$ & 22 особи, $55 \%$ & $-9,3$ & 3,2 & 3,5 \\
\hline Примирення подружжя & 6 осіб, $15 \%$ & $+3,3$ & 6,2 & 6,4 \\
\hline Вагітність, народження дитини & 19 осіб, $47,5 \%$ & $+4,5$ & 7,5 & 8,9 \\
\hline Переривання вагітності & 3 особи, $7,5 \%$ & $-7,7$ & 1,7 & 1,3 \\
\hline $\begin{array}{l}\text { Відокремлення дітей від батьків, } \\
\text { родини }\end{array}$ & 18 осіб, $45 \%$ & 0,75 & 1,5 & 1,5 \\
\hline
\end{tabular}


Продовження табл. 1

\begin{tabular}{|c|c|c|c|c|}
\hline 1 & 2 & 3 & 4 & 5 \\
\hline Втрата роботи, вихід на пенсію & 13 осіб, $32,5 \%$ & $-5,7$ & 5,6 & 2,7 \\
\hline Зміна роботи & 30 осіб, $75 \%$ & $+6,5$ & 7,2 & 7,3 \\
\hline Зміна місця проживання & 38 осіб, $95 \%$ & $+8,5$ & 5,2 & 6,1 \\
\hline $\begin{array}{l}\text { Сексуальні проблеми або } \\
\text { неприємний сексуальний досвід }\end{array}$ & 19 осіб, $47,5 \%$ & $-7,4$ & 6,5 & 0,6 \\
\hline Суттєві зміни зовнішності & 15 осіб, $37,5 \%$ & $-2,1$ & 0,8 & 2,3 \\
\hline $\begin{array}{l}\text { Конфліктні відносини з } \\
\text { близьким оточенням } \\
\end{array}$ & 40 осіб, $100 \%$ & $-6,6$ & 2,5 & 2,5 \\
\hline $\begin{array}{l}\text { Конфліктні відносини з далеким } \\
\text { оточенням (начальство, сусіди) }\end{array}$ & 8 осіб, $20 \%$ & $-3,4$ & 0,3 & 1,7 \\
\hline Позика на велику покупку, борги & 6 осіб, $15 \%$ & $-5,4$ & 8,1 & 4,5 \\
\hline $\begin{array}{l}\text { Зміна посади, підвищення } \\
\text { службової відповідальності }\end{array}$ & 5 осіб, $12,5 \%$ & $+7,7$ & 6,4 & 5,5 \\
\hline $\begin{array}{l}\text { Видатне особисте досягнення, } \\
\text { успіх }\end{array}$ & 40 осіб, $100 \%$ & $+9,0$ & 6,5 & 6,5 \\
\hline $\begin{array}{l}\text { Неуспіх, невдача у значущій } \\
\text { діяльності }\end{array}$ & 27 осіб, $67,5 \%$ & $-7,5$ & 8,5 & 8,6 \\
\hline $\begin{array}{l}\text { Початок або закінчення } \\
\text { навчання }\end{array}$ & 30 осіб, $75 \%$ & 0,4 & 5,6 & 4,3 \\
\hline $\begin{array}{l}\text { Конфлікти з держустановами, } \\
\text { адміністративні покарання, } \\
\text { штрафи }\end{array}$ & 7 осіб, $17,5 \%$ & $-2,8$ & 0,7 & 1,2 \\
\hline Дорожньо-транспортні пригоди & 4 особи, $10 \%$ & $-7,1$ & 0,5 & 0,9 \\
\hline Зміна звичок, способу життя & 40 осіб, $100 \%$ & $+2,5$ & 4,1 & 4,4 \\
\hline Участь у військових діях & 4 особи, $10 \%$ & $-7,6$ & 7,3 & 7,8 \\
\hline $\begin{array}{l}\text { Свідок драматичних подій у } \\
\text { житті інших людей }\end{array}$ & 22 особи, $55 \%$ & $-3,4$ & 2,6 & 0,9 \\
\hline \multicolumn{5}{|c|}{$\begin{array}{c}\text { Стресові подї порушення звичного способу життя } \\
\text { всієі спільноти }\end{array}$} \\
\hline Природне лихо & 12 осіб, $40 \%$ & $-6,7$ & 5,5 & 4,3 \\
\hline Техногенна катастрофа & 36 осіб, $90 \%$ & $-4,6$ & 3,5 & 3,8 \\
\hline Економічна криза & 40 осіб, $100 \%$ & $-6,5$ & 3,7 & 6,8 \\
\hline Соціально-політичні потрясіння & 40 осіб, $100 \%$ & $-3,0$ & 1,8 & 2,5 \\
\hline Військові конфлікти & 40 осіб, $100 \%$ & $-8,5$ & 7,5 & 2,6 \\
\hline
\end{tabular}


Отже, переживання індивідуальних життєвих стресів ускладнене за рахунок глобальної кризової ситуації, у якій неминуче доводиться існувати, а також важкодоступності зовнішніх ресурсів допомоги. Це виснажує адаптаційні резерви особистості й ускладнює переживання криз.

Важливо підкреслити, що значущість одних і тих самих стресових подій сильно відрізняється в окремих індивідів (у таблиці вказані середні показники оцінок впливу події, виставлених за 10-бальною шкалою).

За результатами дослідження виявлено, що найбільший негативний афектогенний потенціал (тобто здатність викликати сильні емоції) мають такі події життя: розлучення або розрив із коханою людиною; важке захворювання; травма, що викликає страх смерті; військові конфлікти й участь у військових діях; смерть близької людини; переривання вагітності; неуспіх, невдача у значущій діяльності; сексуальні проблеми або неприємний сексуальний досвід. Найбільшим позитивнил елоційнил потенціалол володіють такі ситуації: видатне особисте досягнення, успіх, зміна місця проживання, підвищення посади, одруження, весілля та зміна роботи.

Водночас афектогенність події не зумовлює її однозначного впливу на думки та поведінку людини. Найсильніший вплив на поведінкову активність особистості мають одруження і народження дітей, важка тривала хвороба (як власна, так і близької людини), зміна роботи, невдача у значущій діяльності й участь у військових діях. Стосовно впливу на думки й уявлення про життя опитувані найвище оцінили вплив тих самих ситуацій, а також досвід великих фінансових боргів.

Такі закономірності раніше вже були описані в науковій літературі. Наприклад, у рамках особистісно-ситуаційного підходу О. Коржова виокремлює «сильні» й «слабкі» ситуації, які відрізняються виразністю реакцій випробовуваних на ту чи іншу подію. Існують сильні негативні (смерть батьків або дітей) і сильні позитивні (народження 
дітей та онуків, одужання, поїздка на відпочинок, повернення до роботи, закінчення навчання дітей) ситуації. У «слабких» ситуаціях велика роль особистісних особливостей. Виокремлення «сильних» ситуацій дає змогу прогнозувати реакції на певну подію. «Слабкість» ситуації вказує на ефективність апеляції до особистості у процесі психокорекції, на можливість змінити систему ставлення до болісної ситуації (Коржова, 2006).

Таблиця 2

Узагальнені результати вимірювання базисних переконань $(\mathrm{N}=40)$

\begin{tabular}{|l|c|c|}
\hline & $\begin{array}{c}\text { Середні } \\
\text { тенденції } \\
\text { вибірки } \\
\mathbf{( M \pm \sigma )}\end{array}$ & $\begin{array}{c}\text { Частка осіб із } \\
\text { відхиленням } \\
\text { від норми } \\
\text { (менше 12 балів) }\end{array}$ \\
\hline Доброзичливість світу & $16,5 \pm 1,12$ & 3 особи, $7,5 \%$ \\
\hline Доброзичливість людей & $15,7 \pm 1,25$ & 2 особи, $5 \%$ \\
\hline Справедливість світу & $13,8 \pm 1,35$ & 6 осіб, $15 \%$ \\
\hline Контрольованість світу & $16,1 \pm 0,81$ & 2 особи, $5 \%$ \\
\hline Випадковість подій & $14,5 \pm 2,16$ & 5 осіб, $12,5 \%$ \\
\hline Цінність власного «Я» & $17,2 \pm 1,88$ & - \\
\hline Ступінь самоконтролю & $17,9 \pm 1,62$ & - \\
\hline Ступінь успіху або везіння & $15,2 \pm 2,35$ & 4 особи, $10 \%$ \\
\hline
\end{tabular}

Із даних описової статистики ми бачимо, що опитувані мають переважно позитивні уявлення про себе і світ (не виключаємо, що в цьому випадку має місце вплив соціальної бажаності). Серед окремих шкал опитувальника найвиразніші відхилення від «здорової» системи базисних переконань виявлені за шкалами «справедливість світу» та «випадковість подій» .

Кореляційний аналіз показав велику кількість значущих зв’язків між насиченістю автобіографії стресовими подіями та показниками базисних переконань. У першу 
чергу, слід звернути увагу на те, що чим більше у житті людини стресових подій, тим менші оцінки вона ставить значущості їхнього впливу на власні емоції, когніції та поведінку ( $\leq 0,05)$. Отже, важкий життєвий досвід викликає певну толерантність до стресових подій - неминучі повсякденні труднощі та проблеми не викликають занадто гострих емоційних реакцій (це можливо внаслідок звикання / тренування і розвитку стресостійкості або ж, навпаки, через механізм психологічних захистів унаслідок вичерпаності адаптаційних ресурсів).

таблиця 3

Кореляційний аналіз даних, $\mathrm{N}=40$

\begin{tabular}{|c|c|c|c|c|c|c|}
\hline & 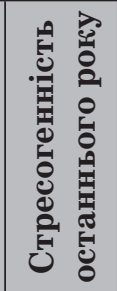 & 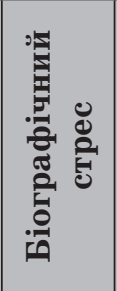 & 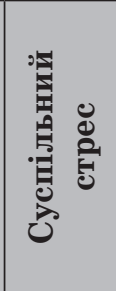 & 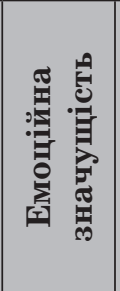 & 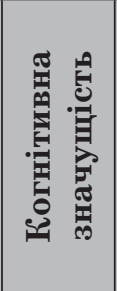 & 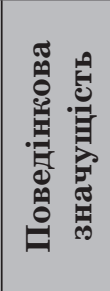 \\
\hline Доброзичливість світу & $-0,384$ & $-0,388$ & $-0,411$ & 0,374 & 0,362 & 0,371 \\
\hline Доброзичливість людей & $-0,398$ & $-0,409$ & $-0,393$ & 0,340 & 0,324 & 0,336 \\
\hline Справедливість світу & 0,168 & 0,182 & 0,262 & $-0,352$ & $-0,365$ & $-0,356$ \\
\hline Контрольованість світу & 0,384 & 0,388 & 0,425 & $-0,374$ & $-0,362$ & $-0,371$ \\
\hline Випадковість подій & 0,218 & 0,231 & 0,302 & $-0,376$ & $-0,385$ & $-0,378$ \\
\hline Цінність власного «Я» & 0,356 & 0,363 & 0,393 & $-0,394$ & $-0,388$ & $-0,416$ \\
\hline Ступінь самоконтролю & $-0,168$ & $-0,182$ & $-0,262$ & 0,352 & 0,365 & 0,356 \\
\hline \begin{tabular}{|l|} 
Ступінь успіху або \\
везіння
\end{tabular} & 0,218 & 0,231 & 0,302 & $-0,376$ & $-0,385$ & $-0,378$ \\
\hline
\end{tabular}

Ми бачимо, що насиченість життя стресовими подіями (в усіх аспектах) негативно і достатньо сильно корелює 3 показниками «доброзичливість навколишнього світу» та «доброзичливість людей». Насиченість життя кризовими подіями негативно позначається на базисних переконаннях про доброзичливість навколишнього світу. Такий ре- 
зультат цілком логічний, адже світ об’єктивно постає для людини небезпечним місцем, сповненим тривог і розчарувань.

Водночас насиченість життя стресовими подіями позитивно корелює з базисним переконанням про контрольованість навколишнього світу. Особливо це стосується показника соціального стресу ( $\mathrm{p} \leq 0,01)$. Отже, внаслідок частого переживання криз у людини розвивається стійке переконання про те, що нещасть можна уникнути, якщо не допускати помилок, докладати зусилля для власного захисту i відвернення неприємностей. Вочевидь, це має охоронну функцію і дійсно сприяє подоланню труднощів. Проте подібна установка може зумовлювати посилення емоційної напруги через постійне очікування неприємностей.

Виявлені прямі зв' язки між виразністю стресів і базисним переконанням про цінність власного «Я» $(p \leq 0,05)$. Отже, досвід вирішення та переживання проблем формує ставлення до себе як гарної та гідної людини, якій немає чого соромитись.

Оцінки впливовості стресових подій на емоції, когніції та поведінку демонструють кореляції з усіма без винятку базисними переконаннями особистості. Але характер цих взаємозв'язків різний. Прямі кореляції спостерігаються стосовно параметрів «доброзичливість світу», «доброзичливість людей» $\mathrm{i}$ «ступінь самоконтролю». Можемо проінтерпретувати це таким чином: людина, котра живе в переконанні відносно того, що світ загалом є гарним місцем, люди в ньому добрі й готові прийти на допомогу, а сама вона достатньою мірою здатна контролювати події власного життя при зіткненні з життєвими труднощами, виявля-

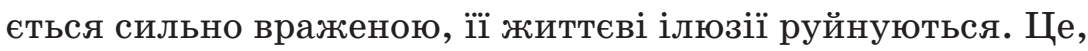
в свою чергу, викликає не тільки болісні емоційні переживання, але й відповідні перебудови когнітивних схем і поведінкових звичок.

Базове переконання про справедливість навколишнього світу (справедливість, контрольованість світу та розпо- 
діл випадковості подій) має негативні кореляційні зв'язки з параметрами суб'єктивної значущості стресів. Така сама картина спостерігається стосовно показників цінності власного «Я» та впевненості у своєму везінні. Для пояснення цих закономірностей, можливо, слід провести додаткове дослідження, що стосується інших чинників переживання та подолання кризових ситуацій.

Стосовно отриманих емпіричних результатів слід згадати дослідження Д. Савельєва, котрий порівняв особливості переживання кризи ідентичності у людей, які долали важкі життєві ситуації самостійно або за допомогою психолога. Результати засвідчили виразність внутрішньо-особистісного та міжособистісного конфліктів у осіб, які звернулися за психологічною допомогою. Вони порівняно високо оцінюють себе, але демонструють виразну дезінтеграцію у сферах: роботи, матеріального забезпечення, внутрішнього світу, здоров'я, сімейних відносин, взаємовідносин із суспільством, а також у сприйнятті власного майбутнього. Натомість в осіб, які самостійно справляються з життевими проблемами, виразнішими виявилися параметри відносин із навколишніми, довіри, очікуваного ставлення від інших, загальної інтернальності й інтернальності в сфері досягнень, невдач, у сімейних і виробничих відносинах, у ставленні до здоров'я і хвороб (Савельев, 2009). Отримані результати підтверджують отримані нами дані, що стосуються високої самооцінки та негативного сприйняття навколишнього світу.

\section{Висновки}

Проведене дослідження дозволило нам сформулювати низку теоретичних і практичних висновків відповідно до поставлених завдань:

1. Криза - загальна назва, що об’єднує різні групи внутрішніх станів і зовнішніх ситуацій: життєві випробування, що неминуче трапляються на шляху кожної людини. Це потребує внутрішньої роботи з перебудови базових 
життєвих установок (ставлень до себе, до інших людей і до світу загалом), ціннісної переорієнтації, відновлення життєвих цілей і планів, а також пошуку внутрішніх ресурсів ї реалізації.

2. За результатами інтерв'ю складено докладний перелік визначальних життєвих подій: особисті успіхи, народження i дорослішання дітей, одруження, кризи стосунків, тяжкі хвороби, зміна місця проживання, роботи i навчання, небезпечний досвід, значущі покупки, образи, зради й конфлікти, втрата близьких людей, подорожі, перебування свідком чужої трагедії. За співвідношенням позитивних і негативних подій у життєвих самоописах $22,2 \%$ вибірки демонструють перевагу негативних подій. Це відображує як насиченість життєвого шляху труднощами, так i загальний знак світосприйняття людини. Феноменологічний спектр індивідуальних наслідків кризових подій досить широкий: набуття досвіду, підтвердження соціального статусу, здібностей і компетентностей, усвідомлення власної відповідальності, зникнення або відновлення сенсу життя, початок нового життєвого етапу, важливий життєвий вибір, розширення можливостей, подолання страхів, переоцінка цінностей i формування нових життєвих стереотипів.

3. Вимірювання загального рівня біографічного стресу (впродовж останнього року та впродовж усього життя) показало, що в житті сучасних українців представлений широкий діапазон кризових ситуацій, включаючи найважчі. Має високий рівень представленість стресових подій порушення звичного способу життя всієї спільноти: природні й техногенні катастрофи, неодноразові економічні кризи, соціально-політичні потрясіння, військовий конфлікт.

4. Кореляційний аналіз виявив, що чим більше життя людини насичене стресовими подіями, тим менші оцінки вона ставить значущості їх впливу на власні емоції, когніції та поведінку і тим у меншому ступені демонструє здатність долати кризи шляхом особистісного зростання. 
Насиченість життя кризовими подіями негативно позначається на базисних переконаннях про доброзичливість світу та людей і водночас позитивно корелює з переконанням про контрольованість навколишнього світу. Це має захисну функцію і сприяє подоланню труднощів, але зумовлює посилення емоційної напруги. Людина, котра живе в переконанні, що світ є гарним місцем, люди в ньому добрі й готові допомогти, а сама вона достатньою мірою здатна контролювати події власного життя, внаслідок зіткнення 3 життєвими труднощами відчуває болісну руйнацію життєвих ілюзій. Це стимулює відповідні перебудови когнітивних схем і поведінкових звичок.

Наше дослідження пояснило формування схем, що стосуються негативного сприйняття навколишнього світу та посиленої самоцінності в осіб, які мають високий рівень біографічного стресу. Для практичного психолога важливо розпізнати характер переживання кризових життєвих явищ і допомогти використовувати ці зміни як джерело особистісного зростання. Аналіз базисних переконань дозволяє суттєво розширити розуміння кризи, досягти більшого ефекту в кризовому консультуванні та кризовій терапії.

\section{Література}

Келли Д. А. Теория личности. Психология личных конструктов / Пер. с англ. А. Алексеева. Санкт-Петербург : Речь, 2000. 249 с.

Коржова Е. Ю. Психология жизненных ориентаций человека. СанктПетербург : Изд-во РХГА, 2006. 384 с.

Кравцова О. А. Сексуальное насилие как психологическая травма: дис. ... канд. психол. наук: 19.00.01. Москва, 2000. 193 с.

Падун М. А., Котельникова А. В. Психическая травма и картина мира. Теория, эмпирия, практика. Москва : Институт психологии РАН, 2012. $133 \mathrm{c}$.

Психологія життєтворення особистості в сучасному світі: монографія / За ред. Т. М. Титаренко; Національна академія педагогічних наук України, Інститут соціальної та політичної психології. Київ : Мiленіум, 2016. $320 \mathrm{c}$.

Савельев Д. И. Психологическое содержание кризиса идентичности личности. Известия Российского государственного университета ил.А. И. Гериена. 2009. № 116. С. 276-283. 
Талеб Н. Н. Антихрупкость. Как извлечь выгоду из хаоса / Пер. с англ. Н. Караев. Москва : КоЛибри, Азбука-Аттикус, 2016. 768 с.

Титаренко Т. М. Жћиття як будівельний майданчик: особисті наслідки посттравматичного досвіду. Психологічна дополога особистості в складних обставинах життедіяльності: Збірник доповідей все українського наук.-практ. селінару, 18 травня 2018 р. Чернівці : ЧНУ ім. Ю. Федьковича, 2018. С. 6-9.

Чиханцова О. ЖКиттєстійкість та ї̈ зв'язок із цінностями особистості. Проблели сучасної психологї: Збірник наукових праць Кал'янець-Подільського національного університету ілені Івана Огієнка, Інституту психології ілені Г. С. Костюка НАПН Украӥни / За наук. ред. С. Д. Максименка, Л. А. Онуфрієвої. Кам'янець-Подільський : Аксіома, 2018. Вип. 42. С. 211-231. DOI 10.32626/2227-6246.2018-42.211-231.

Ядов В. А. Саморегуляция и прогнозирование социального поведения личности: диспозиционная концепция. 2-е расширенное изд. Москва : ЦСПиМ, 2013. 376 с.

Bede, J. (2004). Loss of assumptive world - How we deal with death and loss. Omega-Journal of Death and Dying, 50 (4), 255-265. Retrieved from https://journals.sagepub.com/doi/abs/10.2190/GXH6-8VY6BQ0R-GC04.

Kobasa, S. (1979). Stressful life events, personality, and health: An inquiry into hardiness. Journal of Personality and Social Psychology, 37, 1-11. Retrieved from http://dx.doi.org/10.1037/00223514.37.1.1.

Maddi, S. (2004). Hardiness: An operationalization of existential courage. Journal of Humanistic Psychology, 44, 279-298. Retrieved from https://journals.sagepub.com/doi/10.1177/0022167804266101.

Osin, E. (2008). Subjective alienation: Measurement and correlates. International Journal of Psychology, 43, 509. Retrieved from http://gateway.webofknowledge.com/gateway/Gateway.cgi?GWVersion=2\&S rcAuth $=$ ORCID\&SrcApp=OrcidOrg\&DestLinkType=FullRecord\&D estApp=WOS_CPL\&KeyUT=WOS:000259264306001\&KeyUID $=$ W OS:000259264306001.

Janoff-Bulman, R. (1992). Shattered assumptions: Towards a new psychology of trauma. New York : Oxford University Press. 256 p.

\section{References}

Kelly, G. A. (2000). Teorija lichnosti. Psihologija lichnyh konstruktov [Personality theory. Psychology of personal constructs]. A. Alekseeva (Trans.). Sankt-Peterburg [in Russian].

Korzhova, E. Ju. (2006). Psihologija zhiznennyh orientatsij cheloveka [Psychology of life orientations of a person]. Sankt-Peterburg [in Russian]. 
Kravtsova, O. A. (2000). Seksual'noe nasilie kak psihologicheskaja travma [Sexual abuse as a psychological trauma]. Candidate's thesis. Moskva [in Russian].

Padun, M. A., \& Kotel'nikova, A. V. (2012). Psihicheskaja travma i kartina mira. Teorija, jempirija, praktika [Mental trauma and a picture of the world. Theory, empiricism, practice]. Moskva : Institut psihologii RAN [in Russian].

Hundertailo, Yu. D., Klymchuk, V. O., \& Kliapets, O. Ya. (2016). Psykholohiia zhyttietvorennia osobystosti $v$ suchasnomu sviti [Psychology of life way of personality in the modern world]. T. M. Tytarenko (Ed.). Kyiv : Milenium [in Ukrainian].

Savel'ev, D. I. (2009). Psihologicheskoe soderzhanie krizisa identichnosti lichnosti [Psychological content of the identity crisis]. Izvestija Rossijskogo gosudarstvennogo universiteta im. A. I. Gertsena - News of Hertsen Russian state university, 116, 276-283 [in Russian].

Taleb, N. N. (2016). Antihrupkost'. Kak izvlech' vygodu iz haosa [Anti-fragility. How to benefit from chaos]. N. Karaev (Trans.). Moskva [in Russian].

Tytarenko, T. M. (2018). Zhyttia yak budivelnyi maidanchyk: osobysti naslidky posttravmatychnoho dosvidu [Life as a construction site: the personal effects of post-traumatic experience]. Psykholohichna dopomoha osobystosti $v$ skladnykh obstavynakh zhyttiediialnosti Psychological assistance of the individual in difficult circumstances of life: Collection of reports of All-Ukrainian scientific and practical workshop. (pp. 6-9). Chernivtsi : ChNU im. Yu. Fedkovycha [in Ukrainian].

Chykhantsova, O. (2018). Zhyttiestiikist ta yii zviazok iz tsinnostiamy osobystosti [Hardiness and its Relationship with the Values of the Personality]. Problemy suchasnoi psykholohii - Problems of modern psychology: Collection of Research Papers of Kamianets-Podilskyi National Ivan Ohiienko University and G. S. Kostiuk Institute of Psychology of the National Academy of Educational Sciences of Ukraine, 42, 211-231. DOI 10.32626/2227-6246.2018-42.211-231[in Ukrainian].

Jadov, V. A. (2013). Samoreguljatsija i prognozirovanie sotsial'nogo povedenija lichnosti: dispozitsionnaja kontseptsija [Self-regulation and prediction of social behavior of an individual: dispositional concept]. Moskva [in Russian].

Kobasa, S. (1979). Stressful life events, personality and health. Journal of Personality and Social Psychology, 37, 1-11. Retrieved from www. researchgate.net/publication/22682825.

Maddi, S. (2004). Hardiness: An operationalization of existential courage. Journal of Humanistic Psychology, 44, 279-298. Retrieved from https://journals.sagepub.com/doi/10.1177/0022167804266101. 
Osin, E. (2008). Subjective alienation: Measurement and correlates. International Journal of Psychology, 43, 509. Retrieved from http://gateway.webofknowledge.com/gateway/Gateway.cgi?GWVersion=2\&S rcAuth $=$ ORCID\&SrcApp=OrcidOrg\&DestLinkType $=$ FullRecord $\& D$ estApp=WOS_CPL\&KeyUT=WOS:000259264306001\&KeyUID $=\mathrm{W}$ OS:000259264306001.

Janoff-Bulman, R. (1992). Shattered assumptions: Towards a new psychology of trauma. New York : Oxford University Press.

\section{Тавровецька Наталія. Емпіричне дослідження базисних переконань особистості в контексті подолання життєвих криз}

\section{АНОТАЦІЯ}

У статті розглянуто теоретичні та практичні підходи у дослідженні базисних переконань особистості в контексті подолання життєвих криз. Поняття "базисні переконання» проаналізовано з когнітивної, соціальної та екзистенційної позицій. Зазначено, що травматична стресова подія є досвідом гострого і раптового зіткнення переконань людини з реальністю, й перебіг кризи залежитеме від життєстійкості людини, від рівня порушення смислових зв'язків у структурі життєвого світу особистості, що лежить в основі смисловтрати.

Проаналізовано концепцію базисних переконань Р. Янофф-Бульман, що пояснює, яким чином індивід конструює свої уявлення про навколишній світ і власне "Я». Базисні переконання - це необхідна внутрішня опора в мінливій реальності, що сприяє психічній стабільності людини ma ії успішності в житті, а також є важливою умовою особистісного розвитку. Але базові переконання змінюються під впливом психічної травми, адже екстремальний негативний досвід різко суперечить описаній концепції життя.

Для визначення рівня та змісту автобіографічного стресу було використано комплекс методів і методик: метод структурованого діагностичного інтерв'ю («Значущі життєві події») для отримання загальної картини позитивної та негативної подієвості автобіографії, закриту анкету "Список стресових подій» з оцінкою значущості їх впливу на емоційному, когнітивному та поведінковому рівнях і Шкалу базисних переконань "World Assumptions Scale» (Р. Янофрф-Бульман).

З'ясовано рівень біографічного стресу в житті сучасних українців, який представлений широким діапазоном кризових ситуацій, включаючи найважчі. Має високий рівень представленість стресових подій, що носять всезагальний характер: природні та техногенні катастрофи, 
неодноразові економічні кризи, соціально-політичні потрясіння, військовий конфлікт.

Проведено кореляційний аналіз, який доводить, що чим більще життя людини насичене стресовими подіями, тим менші оцінки вона ставить значущості їх впливу на власні емоції, когніції та поведінку $і$ тим у меншому ступені демонструє здатність долати кризи шляхом особистісного зростання. Зроблено висновок, що насиченість життя кризовими подіями негативно позначається на базисних переконаннях про доброзичливість світу та людей і водночас позитивно корелює $з$ переконанням про контрольованість навколишнього світу.

Ключові слова: базисні переконання, життєві кризи, автобіографічний стрес, емоційна, дієва та когнітивна поведінка.

Тавровецкая Наталья. Эмпирическое исследование базисных убеждений личности в контексте преодоления жизненных кризисов

\section{АННОТАЦИЯ}

В статье рассмотрены теоретические и практические подходы в исследовании базисных убеждений личности в контексте преодоления жизненных кризисов. Понятие "базисные убеждения» анализируется с когнитивной, социальной, экзистенциальной позиций. Отмечено, что травматическое стрессовое событие - это опыт острого и внезапного столкновения убеждений человека с реальностью, и ход кризиса будет зависеть от жизнестойкости человека, от степени нарушения смысловых связей в структуре жизненного мира личности, что есть основой смыслопотери.

Проанализирована концепция базисных убеждений Р. Янофрф-Бульман, которая объясняет, каким образом индивид конструирует свои представления об окружающем мире и собственном "Я». Базисные убеждения - это необходимая внутренняя опора в меняющейся реальности, они способствуют психической стабильности человека и его успеху в жизни, а также являются важным условием личностного развития. Но базовые убеждения меняются под влиянием психической травмы, ведь экстремальный отрицательный опыт резко противоречит описанной концепции жизни.

Для определения уровня и содержания автобиографического стресса был использован комплекс методов и методик: метод структурированного диагностического интервью («Значимые жизненные события») для получения общей картины положительной и отрица- 
тельной событийности автобиографии, закрытая анкета "Список стрессовых событий» с оценкой значимости их влияния на эмоциональном, когнитивном и поведенческом уровнях и шкала базисных убеждений «World Assumptions Scale» (Р. Янофрф-Бульман).

Выяснено уровень биографического стресса в жизни современных украинцев, который представлен широким диапазоном кризисных ситуаций, включая тяжелые. Имеет высокий уровень представленности стрессовых событий, носящих всеобщий характер: природные и техногенные катастрофы, неоднократные экономические кризисы, социально-политические потрясения, военный конфликт.

Проведен корреляционный анализ, который доказывает, что чем больще жизнь человека насыщена стрессовыми событиями, тем меньше оценки он ставит значимости их влияния на собственные эмоции, когниции и поведение, и тем в меньшей степени демонстрирует способность преодолевать кризисы путем личностного роста. Сделан вывод, что насыщенность жизни кризисными событиями негативно сказывается на базисных убеждениях о доброжелательности мира и людей, и в то же время положительно коррелирует с убеждением о контролируемости окружающего мира.

Ключевые слова: базисные убеждения, жизненные кризисы, автобиографический стресс, эмоциональное, действенное и когнитивное поведение. 